\title{
Khamosh Pani: Partition trauma, gender violence, and religious extremism in Pakistan
}

\author{
Faizullah Jan*1 ${ }^{*}$ Syed Irfan Ashraf ${ }^{1} \mid$ S. Fawad Ali Shah ${ }^{2}$
}

1. Department of Journalism \& Mass Communication, University of Peshawar, Peshawar, Pakistan.

2. Department of Communications, Jacksonville State University, Alabama, United States.

* Corresponding Author Emails: faiz.jan@uop.edu.pk | faiz.jan@gmail.com

\begin{abstract}
This paper looks at the question of partition of British India in 1947 and the rise of religious extremism in Pakistan through an analysis of internationally acclaimed and award-winning Pakistani film Khamosh Pani (silent waters). The paper uses Symbolic Interactionism and Feminist Theory with a critical perspective to establish how the present-day religious extremism in Pakistan has its roots in the colonial history of the country. However, it also highlights the diagnostic inability of Symbolic Interactionism as it smacks of the volunteerism and overlooks how statist and organized institutional power infringes upon socio-political meaning making processes. This paper argues that the film connects the communal nature of pre-partition violence to grassroots contemporary religious extremism in Pakistan to show how the rupture of a village life is the continuation of colonial heritage of communal violence. We argue based on the findings of this study that religious extremism that is manifest in today's Pakistan is not a break from the past; instead, it is rooted in the colonial history connecting the national Pakistani elite with the regional neo-colonial interests.
\end{abstract}

Article History

Received:

October 19, 2020

Last Revised:

March 6, 2021

Accepted:

March 3, 2021

Published:

April 9, 2021

Keywords: partition, partition of India, gender, feminism, violence, communal violence, gender based violence, patriarchy, colonialism, neo-colonialism, imperialism.

\section{How to Cite:}

Jan, F., Ashraf, S. I. \& Shah, S. F. A. (2021). Khamosh Pani: Partition trauma, gender violence and religious extremism in Pakistan. Liberal Arts \& Social Sciences International Journal (LASSIJ), 5(1), 16-27. https://doi.org/10.47264/idea.lassij/5.1.2

\section{Publisher's Note:}

IDEA PUBLISHERS (IDEA Journals Group) stands neutral with regard to the jurisdictional claims in the published maps and the institutional affiliations.

Copyright: (C) 2021 The Author(s), published by IDEA PUBLISHERS (IDEA Journals Group). This is an Open Access article published under the Creative Commons Attribution-NonCommercial 4.0 International License (http://creativecommons.org/licenses/by-nc/4.0/) 


\section{Introduction}

'Khamosh Pani' (silent waters, 2003, directed by Sabiha Sumar) is a feature length historical drama based on a true story of a Pakistani village shown as a microcosm of the pangs of the spatial division of the Indian Subcontinent. The film is shot in the wider context of the 'Partition' and the consequent birth of India and Pakistan as two 'independent' countries, following the British 'withdrawal' from India in 1947. Though the metaphor "Partition" represents a communal violence, widely affecting Hindus, Muslims, and Sikhs, but the film specifically focuses on a Sikh family, all the members of which escaped to India except one woman who stayed in Pakistan. The term partition comes loaded with the collective memory of the people - tragic and traumatic - and that of the state institutions, a wound that refuses to heal. Seven decades since that fateful day in August 1947, it continues to impregnate bilateral relations between India and Pakistan with hate, distrust, and mutual hostilities. As a chapter in the mutual histories, the partition of India embodies pain, violence, and uncertainty, forever hanging like a dark cloud overshadowing prospects between the two neighbouring countries.

Reinforcing the old adage that those who don't learn from history are condemned to relive it, the film draws on the historical trauma of the two eras when, despite centuries of common history, some Muslim landlords and business tycoons chose to cement religious differences as a way to define themselves as separate entities and nations. History has come full circle. Today's Pakistan, bearing the hallmarks of extremism with roots in the successive military dictatorships, playing on the distrust that the Partition bred, and the hostilities therein threatens global peace. And this is what contemporary India and Pakistan are reaping: the Modi's regime in India with its violent and intolerant pursuit of reshaping an exclusive India in the vision of a communal Hindutva; and Pakistan where mobs - fed on state-supported anti-Hindu sentiments - vandalize temples and stop the construction of new worship places, minor Hindu girls are kidnaped and then forcibly converted to Islam (Ellis-Petersen, 2020; Mansoor, 2019). It is this cycle of history that makes the film timeless, and attempts to relive, remind, and deliver the warning that such an extremist attitude has a way of perpetuating itself in both the countries, with disastrous grassroots implications for the people who may or may not subscribe to it. Foregrounding the Partition, Silent Waters is both a metaphor and an augury; it foretells signs of destruction approaching the two countries to engulf its people like silent water.

\section{Theoretical framework}

Since its release in 2003, the film won accolades among the critics and the award circuits (BBC News, 2003; Kara Awards, 2003). The debates it generated point to the relevance of its subject matter to our world today-religious extremism undermining peace through hatred and intolerance (Rashid, 2009; Ellis-Peterson, 2020; Gettleman et al., 2020; Dawn, 2011; Economic Times, 2020; The Nation, 2018). This paper, while connecting this general debate to postcolonial State and neo-imperialism, uses Symbolic Interactionism as its theoretical framework. Symbolic Interactionism according to Blumer $(1986 ; 2004)$, is a theoretical framework which suggests that people derive meanings from social interactions and modify through interpretation. We show how a pre-partition relatively meaningful life is subjected to the tragic structure of history in a postcolonial State and the way both - history and postcolonial state-influence everyday life to serve neo-imperial order entailing consequences for local and global security.

The depiction of women and their body in this film nicely fits in the theoretical formulation of 
French scholar Michel Foucault (Foucault, 1978). Foucault in his seminal work Discipline and Punish: The Birth of the Prison (1978), describes how the body of the prisoner was used to be a spectacle of exercising power through punishment (Foucault, 1978). However, Foucault's theorization of power has been critiqued on two accounts; its eraser of women's specific experiences with power and its inability to attend to the prospects and processes of empowerment of women (Deveaux, 1994). Other scholars have highlighted the inadequacy of Foucault's work when it comes to the analysis of subjectivity formation and resistance in the non-European context. Butalia (2000), for instance, criticsezs the male and high-politics centric narratives of partition and brings to light the pain and trauma suffered by marginal populations, especially women.

\section{Research methodology}

This study investigates whether the text of the film Silent Waters flows in alliance with its context or the other way round. To this end, we have employed Symbolic Interactionism, with Critical Feminist Theory as a supplemental analytical tool. The film's cinematic narrative is critically examined to identify the symbolic and gendered themes embedded in it. The narrative devices deployed in the movie have been grounded in their broader socio-political and historico-cultural context to trace the shadow of the past on the present through the mirror of this film.

\section{Partition: a peg that holds organized violence}

The film opens in Charkhi village of Punjab, Pakistan's largest province. It is in this village where the social fabric of a community is slowly tearing apart under the colonial heritage of communal violence. Back in 1947, at the time of Pakistan's independence, Charkhi was home to both Sikhs and Muslims. Charkhi is where Punja Sahib, the second holiest shrine of Sikhism after Golden Temple in Amritsar in India, is also situated. When communal violence ensued after the Partition, most of the Sikh inhabitants of the village fled or were forced to flee. The horrid reality of the Partition hit entire populations seeking to escape the violence but for the women, a vulnerable section of the society, it was especially traumatic as they were kidnapped, raped, and killed by Muslim zealots. Men killing their own women to 'save their honour' was a grisly reality that faced the female population and often there was no escape because they were dependent on men and their decisions. Many women also chose to commit suicide to escape the mass communal insanity.

It is the Pakistan of 1980s. Ayesha, a widowed Muslim woman, lives in Charkhi with her son. Once Ayesha was a young Sikh girl at the time of Partition who did not choose suicide like the other Sikh women when communal violence came to Charkhi in 1947; she did not jump into a well like the other women of her family. Her instincts were that of a young person: to live by fleeing the troubles. But even as she fled, was ambushed by murderous Muslim zealots lying in wait. The choice left to her was to marry a Muslim or die. She chose the former. She forsook her faith and from Veroo, a common Sikh name, became Ayesha, a venerated Muslim name. In time, a son is born to her. Soon after, her Muslim husband died. She had to raise her son Saleem who falls in love with the vivacious Zubaida, a girl from his Muslim-dominated village.

The Pakistan of the 1980s was a country under the twin onslaught of a military dictatorship, General Ziaul Haq, that sought death to democracy and an engineered rebirth of radical Islam as the leitmotif underpinning the governance, legislation, and foreign relations. In the 
neighbouring Afghanistan, a U.S-funded proxy war called Jihad was raging against the Soviet occupation, with Pakistani military training and equipping mujahideen, the Islamist jihadists, with support from the capitalist West and Saudi Arabia (Mark \& Yousaf, 2001). General Zia had turned Pakistan into a veritable theocracy, with a militant Sunni bent (Ali, 2003; Jalal, 2014; Haqqani, 2005). Amidst this, two young preachers come to the village, drunk on the Zia's radical vision of Islamization, seeking to find potential converts to their militant outlook. The situation takes an alarming twist for the community including Ayesha, Saleem's mother, when that year scores of Sikhs arrive from India and Pakistan for their annual pilgrimage to the shrine of Punja Sahib at Charkhi.

Meanwhile, the powerful village landlord extends support to the two religious evangelists in their pursuit to convert young people to their radical cause. Like many youths seeking a purpose in life and a social and political identity, Ayesha's son Saleem is an easy prey to the evangelists. A young and confused orphan, Saleem joins the Islamist group and soon becomes a religious bigot on gaining the identity where people generally lend an ear to his religious views. A newly radicalized Saleem jilts the girl he once loved and questions his own mother's past. Is his mother's faith pure? Is she, as a convert, loyal to Islam? As the young man spends more time with his fanatic friends, their influence on him grows and eclipses all relations. He grows rude to his mother by the day. His new, fanatic friends feed on Saleem's confusion and as he grows distant from his social circle, he questions his own reality where his sense of Ayesha as his mother collides with the religiously fraught knowledge of her as a woman with a Sikh past, "the sister of a (Sikh) non-believer." In this new reality where his mother turns a non-believer, the whole notion of a "family" disintegrates for the radicalized youth because his mother was his family. As is often the case with such youth, the concept of family changes from the social one to a religious one, because the youth feel closer to the outlook of those who radicalized him. They are his family now.

Under pressure from his new friends, Saleem asks his mother to proclaim her faith again in front of a village gathering. For the mother it brings back flashbacks of a painful past because she now sees the reflection of the men who, seized by religious hatred, killed her family on the eve of the Partition. But the village is now completely under the sway of radical religiosity. The villagers, afraid of the backlash from extremists who had become more entrenched in the village affairs and community, shun Ayesha. Persecuted by the religious fringe, abandoned by her family, and banished from the village community under the sway of the fundamentalists, she is driven to a path she once refused to take she rushes out and plunges into the same deep well that she fled from decades ago and where many of her friends had drowned themselves. An unrepentant Saleem grows into the kind of fundamentalist politician that the General Zia regime endorsed and colluded with, to find legitimacy for his brutal Martial Law regime. Despite his rejection, Zubaida stood by Ayesha till last. She soon leaves Charkhi to pursue her education and make a career in the garrison city of Rawalpindi.

Silent Waters underpins the need for a mystical, tolerant Islam. Until Zia's dictatorship and the attendant Afghan Jihad and the Pakistani state's dependence on religious parties to provide proxies for its regional wars, that was the Islam that the people of Pakistan once knew. What began in 1979, replaced the mystical Islam with a demonstrative and intolerant religiosity.

\section{Meaningful life stuck between mosque and state}

Construction of reality is a social process, an interactive communicative phenomenon carried 
out through complex ideological means. American sociologist George Herbert Mead (1962) posits that people do not react directly to events; they act based on their interpretation of the meaning of events or symbols. People assign meanings to objects and events, interpret them, and then react to these according to their subjective interpretation. To frame this ideological process in sociological terms, Blumer $(1986 ; 2004)$ coined the term 'symbolic interactionism' which means that people engage and react to meanings, which are derived from social interaction and modified through interpretation. This is how a particular worldview is constructed through the meaning-making process of symbolic interaction (Pascale, 2011). However, we argue that the emergence of a particular worldview cannot be reduced only to free social interactions. Doing so runs the risk of voluntarism (Hays, 1994), a focus only on the free interplay of relationship in a social sphere without identifying those external influences which shape the ideological sphere. Voluntarism, argues Hays (1994), also suggests an agency on part of the individual, a freedom to choose and to interpret. Since no social interaction is free of State influence in a postcolonial State such as Pakistan, symbolic interactionism is as much a state-peddled ideological process as it is a social phenomenon.

In Silent Waters, the reality of religion and society at large - and even 'motherhood' changes for Saleem with a change in social interaction. A new set of human interactions emerge with the arrival of a group of extremist outsiders in the village who strategically use mosque to interact with youngsters. As a result, new meanings and reinterpretations are created. The emerging worldview not only challenges the free/liberal village spaces, but it also contributes to the inversion of the existing sphere of easy-going village life. After joining the ranks of religious fanatics, in other words, Saleem now has a new concept of reality. In this reality, Ayesha is his mother, but at the same time, she is also what he exactly called her 'the sister of a non-believer (Sikh).'

Associating her mother with a non-believer, Saleem redefines the 'object' of family in relation to the social category 'mother.' Her past religion is signified more than motherhood and Muslim religious 'piety' of his mother. As religious political engineering is fuelled by a bandwagon of backward march to a mythical golden 'unadulterated past,' Zia's Islamizing was also propelled on the gears of religious purification. Saleem's new fanatic peers instigated him to not only 'purify' his own cognitive makeup (memory), but also his mother's. Consequently, he tried to purify, or to use a metallurgical term, 'leach' his mother in the public crucible. Symbolic interactionism forced Saleem to re-interact with himself and his mother - the two major sites and symbols of his interactions. This is how an outside discourse, the outcome of symbolic interactionism, changes the texture of his thoughts, giving altogether new meanings to his outlook on life.

The change in Saleem's worldview was a dominant factor in an overall change in his approach to his own identity. But this transformation was socially overdetermined, the outcome of the process of symbolic interactionism. In an argument with his mother, for instance, Saleem asserts, "now people stop and listen to me. I am somebody [now]." Basking in a new reality, which his extremist social group constructs for him, Saleem reinterprets his village-bound symbols and events. Now that people listen to him with reverence, he smells power.

What is significant about the film is the way it depicts how personal and social contradictions in the life of common people expropriated in Pakistan, politically as well as ideologically, and how this complex process feeds on traumatic memories of the troubled colonial history. For Saleem, his mother's past becomes more significant than her present: a spectre of Partition 
haunts the prospects of living a peaceful life. Now, for Saleem, the very meaning of blood relation has changed. Ayesha was no more his mother-not even a mother figure, much less one who shares his Muslim faith and teaches the Quran to the village children-but the Other, a traitor-in-the-ranks whose lineage could be traced back to the Partition, and to a different faith than his own. At the same time, his former lover, Zubaida, for him becomes someone who tries to "mislead" and "disgrace" him by her love; he feels a threat to his masculinity in Zubaida's determination to pursue education and make a career. Introduced to a militant version of Islam, the village's patriarchal system begins to feed on a festering history and together they all begin to feed the militant spirit of changing time in Zia's Pakistan.

Silent Waters is a depiction of a society which carried a strong undercurrent of imbalance at the gender level. The film depicts a male-dominated society in which masculine power plays out on the body of women. Feminist theory emphasizes that women are discriminated against in a variety of ways and defines the role of sexuality in the matrix of domination. Though it is also true that not all women are oppressed the same way: some face gender inequality and gender differences, while others undergo gender and structural oppression. But what cannot be contested is the (degrees of) "vulnerability" of women and their secondary status in a patriarchal, male-dominated milieu, such as the village in question.

In the same line of argument, feminists like Collins (2008) emphasize an intersectionality to explain oppression and inequality across class, gender, race, ethnicity, and age. Religion is no exception to this list. Out of context readings of sacrosanct text in a domain ruled by hyper masculinities could generate toxic tendencies leading to mass violence, an emerging challenge in the increasingly globalized world, thanks to communication technology that is causing unprecedented time and space collapse. But the less powerful sections of society in a country like Pakistan are also on the receiving end of this global transformation. The crux of feminist theory is that women are oppressed and discriminated against because of their being female, ignoring the role of those global forces overdetermining the already marginalized role of women in society. For Ayesha, a woman in a patriarchal, feudal setting that is a Pakistani village, the dice was already loaded, then, and the only way left was the one that led to the well. That is why many feminists argue that in a patriarchy, the division of labour is contingent on sexist patterning where women are denied the opportunity to express and practice reasoning (Zia A. S., 2018; Butt \& Shahid, 2012; Saigol, 2016). They are restricted to the private sphere of the household and have no voice in the public sphere or decision-making process.

In Silent Waters, the role of Ayesha, Saleem's mother, is also the embodiment of a woman caught in a sphere of toxic masculinities drawing inspiration from the spirit of highly charged political temporality. This temporality was impregnated by the military dictator Zia's policy of military support for 'Afghan Jihad' being fought across the border at the height of Cold War politics in early 1980s. This depiction of women and their body nicely fits in the theoretical formulation suggested by French scholar Michel Foucault (Foucault, 1978). Foucault in his seminal work Discipline and Punish: The Birth of the Prison (1978), describes how the body of the prisoner was used to be a spectacle of exercising power through punishment (Foucault, 1978). This concept explains Ayesha's predicament. The prison is the village, its traditions and customs that places the prisoner in the four walls of her home, a prison within a prison, within which a woman's body is a site for power contestation.

Ayesha's is a disposable body caught between toxic masculinities whose game of hatred leaves little space to make a choice free of the shackles of patriarchy, much less radicalism and 
extremism engendered - in the national, international, regional and the hyper-local domain of a village and community - by men in position of power. This reality is depicted in the film through extremist discourse carried out between religious fundamentalists and patriarchal nationalists who mostly refer to women when they try to explain how and why to save their collective 'honour'. Women are visible in the film, but they are shown caught up in claustrophobic spaces: inside their homes, sewing, cooking, and washing clothes-which reveals how gender inequality is implicit in unpaid labour. When they are shown outside their homes, they are going to fetch water from a community well, or as children going to school. In this patriarchal depiction, women have no agency or capacity for moral reasoning. They are merely disposable bodies working as appendage to the whims of toxic masculinities weaponized by the puritanical Wahabi strand of Islam.

Almost no family relation is outside of the representation of this claustrophobic reality, a complex reality depicted quite effectively in the film weaving a pernicious thread of extremism around a women's body. Saleem, a male member of the family, imposes himself on his mother by making moral arguments with her. Which leaves her speechless when her son questions her loyalty to his religion, i.e., Islam. The tragic drama shows how females, collectively and individually, constitute the honour of their men on both sides of the religious divide. Similarly, when Sikh men talk about their so-called honour, they make frequent references to their 'own' women. For instance, when a group of Sikh pilgrims in Charkhi village shrine reminisces about their pre-Partition life, one of them asks about any Sikh women left behind. This mentioning riles up another Sikh pilgrim who roars with rage at the thought of how a Sikh woman daring to remain behind or ending up in the hands of Muslims. It is a notion repugnant to both religious and ethnic identity. Relations with such women dissolves in the acid of hatred, reinventing life laced with extremism and nationalism. When Ayesha's brother comes to the village to search for his sister, she refuses to recognize him. Thus, she again sacrifices a blood relation to protect the 'honour' of the men.

To overcome this notion, the Sikh pilgrim - as if soothing their ruffled feelings - reassuringly adds, "My uncle had killed 22 women of his family with his own hands to save our honour". Similarly, Muslim extremists [in another scene] rebuke their fellows in these words: "Indians would come and pick our women to dishonour us, while you will be worrying about day-today life."

The effective portrayal of extreme forms of gender inequality is a significant attribute of the film which realistically depicts the way the historic form of pre-Partition violence is strategically transformed into contemporary extremism, colonizing the village space. For example, those men of the village who had converted to Islam - of their own free will or under coercion - are no suspects at all. Interestingly, no-one from their earlier [Sikh] community tries to find out and contact a convert. To restore their lost honour, Sikh men try to trace their leftbehind women, not men. A male convert is spared all the suspicions and tribulations that Ayesha goes through.

The representation of a patriarchal society is a conspicuous theme in the film, a theatre of social existence in which powerholders, feudal and religious figures, display their power. They are creating a social order where children, teenagers and women are 'disciplined' to reinforce the existing social (dis)order. The pack of religious extremists come to Charkhi village where they are hosted by the local feudal lord. In a scene of the film, the landlord gathers local people in the village mosque and after the congregational prayers introduces the young zealots as 
someone who want to strengthen Pakistan and 'save' its society from 'evils'. He asks the people to sit, listen to them and heed their call. Here a triangle of power-politicians, religious figures, and feudals - is all too visible.

The religious zealots do not challenge the power of the feudal lord, who enjoys profligate life among people who barely eke out a living. Ironically, the feudal lord, who throws a sumptuous party at the wedding of his son, with a dance party in which a young female dancer entertains an all-male audience sipping wine, both acts extremely abhorrent to Islam, is looked at as a friend. On the other hand, Ayesha, a practicing Muslim who teaches the Quran to village children and earns a meagre living, is a threat to the society and country. The film shows how nationalism in its narrow form and ideology when supported by the state, cuts through human relations through power and coercion. Saleem's relations with his sweetheart and his mother get transformed after he embraces an artificial ideological religious nationalism which gives him an identity but robs him of human passion.

\section{Pakistan: a society in the throes of engineered transition}

As communication is a symbolic process, Silent Waters depicts a society in the throes of transition at different levels of social and political interaction. At the level of a postcolonial State, the film's tangential depiction of the role of Zia, a military dictator, in introducing extremism in Pakistan takes this symbolic process into a context. The U.S.' support for Zia to use religious extremism for creating local labour to fight offshore war in Afghanistan has long foreshadowed the region's prospects with fateful implications for global security. The emergence of Al-Qaida and its relationship to terrorist attacks in the U.S. defines the context of $9 / 11$ attacks. Created by militarized men of extreme patriarchal and religious views, the local theatres of global militarization continue to oppress women long after the colonizing West, which toady champions equal rights, has long exited the arena. Silent Waters apparently does not establish this connection up front yet it opens a vast symbolic space in which organic social reality is produced, maintained, transformed, or displaced. This strategic, contextual spatial insight that the film provides identifies a metaphorical transformation of the historical phase of distant village life into an immediate form of contemporary global level destruction - the "war on terror."

How the State creates ruptures in a meaningful life is embodied in the film through the microcosm (or character) of Saleem. His radicalization was part of the State ideology, an outside extremism plagues the village life. This political and ideological transition reinforced the village patriarchal order without challenging the existing power equation. Thus, extremism was a political and imperial phenomenon which was brought to the village from the outside, but it enhanced the power of the powerful and intensified the subjugation of the common people in the name of religion. Those who already have a power because of their economic clout, need not to change themselves. Only plebeians must re-align themselves to new realities of life because power resides in the same old centres. Partition not just maintains its existence in the State apparatus, but it also became a symbolic medium not just to maintain memories in their dormant form, but the essence of these tragic stories enables the State to transform and displace local subjectivities.

The structure of oppression cannot escape the determination of human struggle as Foucault (1988) establishes in his famous adage: where there is power, there is resistance. However, this beautifully rendered melodrama does not show any resistance by women who are constantly 
coerced into submission. The only resistance conveyed is in the subtle defiance of Zubaida, Saleem's lover, of the village's patriarchal traditions and conventions. She completes her education and finds work in Rawalpindi, a garrison city, an irony. It is a form of resistance to the feudal patriarchal conventions of rural Pakistan but not to the larger coercion of the State and the society it shapes. As a young woman, her struggle is against her immediate circumstances that constrict her potentials. In the end, she must find means of survival within the working of the crushing, soulless manipulations of the State. Perhaps they are not as overtly visible and fathomable to young (rural) women, just as they are not to men like Saleem, fed on an education built on false, misplaced notions of patriotism and historical lies and distortions.

But a profound resistance that the film represents is that of imagination, the medium and the message it embodies. In other words, the production of this movie itself is a form of defiance, a meaning making cultural artifact that is steeped in storytelling. Through local characters, a common parlance and history and setting, the film resonates with viewers at a level deeper than one that is aimed at entertainment alone. Silent Waters reflects the global scope of representation of local life. It uses a mixed medium of Punjabi and Urdu languages with subtitles in English language. In that sense, it complements the past and present efforts of the political and civil society organizations that resist hegemony and power, offering a grounded view of local socio-cultural milieu to help understand society as a condition of possibilities. From this perspective, Silent Waters cautions us that meaning making could not just be derived from social interactions or modified through cultural interpretations, but the powerful role of the State apparatuses using history as a meaning making repository is also inescapable.

Though the film does not take away anything by way of the facts that constitutes the contemporary Pakistani and regional reality, it surely lacks an insight into the much-needed background. The group of fanatics in the film frequently refer to 'Lahore,' the provincial capital of Pakistan's powerful Punjab province, a city which is familiar to the Pakistani audience. However, this can be confusing for non-Pakistani audience. The Jama'at-i-Islami, Pakistan's main religio-political party, has been the driving force behind religious extremism in the country. General Zia's dictatorship spearheaded the Jama'at's extremist ideology in the name of Islam. It is headquartered in Lahore. When the young missionaries who come to the village to indoctrinate the youth refer to Lahore, they mean the Jama'at's headquarters or the party itself. Importantly, the physical battleground for the extremist mind, which Zia nurtured, was and still is the tribal areas of Pakistan. The mention of Lahore identified the mindset, ideological hub but makes no reference to tortured bodies other than women. We should not forget that five million Pashtuns (Pakistan Bureau of Statistics, 2017) live in the tribal districts of Pakistan (formerly called FATA) whose lives have been torn to shreds by the Zia and Musharraf regimes' policy of injecting extremism to produce manpower for fighting the U.S.funded jihad in Afghanistan.

Silent Waters makes for an evocative and unsettling imagining of how historical form of trauma is appropriated by imperialist politics to produce religious fanaticism as a matter of policy. Extremism, it suggests, is not an ontological phenomenon. Nor could it be related to civil society only. Overlooked or tolerated, or subtly or outrightly supported by State and law enforcement institutions, extremist organizations reach out to the poor, creating identity crisis and thriving on it. This situation exposes vulnerable people, especially youth to coercion and exploitation. By joining a radical and puritanical organization, they get recognition and a voice, which translate into a semblance of power. After acquiring a nuisance value through overt religiosity, they become 'somebody' from 'nobody'. This is the work of post-colonial artificial 
Pakistani nationalism, hegemony and ideology that regularly unleashes political and religious extremism. Silent Waters makes us aware of the much talked about but not well-attended threat of ideological extremism that is powerfully asserting itself at the global scene, often with impunity and in varied ways and forms.

\section{Conclusion}

Silent Waters is set in a Pakistani village with a focus on a local family, but the film's underlying thematic relevance is much wider than that. The film shows that social reality in Pakistan is not merely a function of symbolic interactionism, a free flow of productive information or interpretation required for the maintenance or transformation of a society; rather it is a hard battle for the domination between everyday agents and pernicious postcolonial structures - history as a spectre of violence and State as a system of colonial legacy. Silent Waters identifies and connects the extremism as a malevolent force causing not just identity crises in the local lives of common people, but also identifies how this displacement at the local level surfaces now and then at the global level to poison our collective historical past, present and the future.

In 1979, the Soviet intervention in Afghanistan at the peak of the Cold War politics brought the military dictator, General Zia of Pakistan, on the same page with the Western capitalist notions of threat to the "free world" - as it did another Pakistani military dictator Gen. Pervez Musharraf in the post-9/11 world (Mark \& Yousaf, 2001). These regional imperialist wars were the inculcation of extremism that turned common people, mostly Pashtuns, into laborers in the imperialist tradition. Fighting a decades-long proxy war, the capitalist bloc by using local youth as fodder, armours, and fighters forced the Soviets out of Afghanistan, but the war also took a heavy toll on Pakistani society, specifically on the Pashtuns of the tribal areas. Silent Waters depicts this crucial phase of the regional history with a focus on the radical transformation of everyday life in a small village. It shows how the silent water of State-sponsored extremism wiped out the basic unit of family in a country where 63.33 per cent people live a marginalized rural life (Macrotrends, 2018).

The film makes a vital contribution to the representation of regional history, connecting Islamic militancy (jihad) and the U.S. imperialism, a portrayal that unearths those fault lines that enabled the Pakistani State to impose insanity on a village life. In other words, the interplay of local patriarchy, colonial history and State-sponsored jihad are the dominant themes of the film that show how extremism in Pakistan took birth on the cusp of meta-structural forces. From this perspective, the film takes up the task of showing how the social fabrics in a rural set-up broke apart because of outside pressures and how this displacement gave way to a statesponsored militant Islam, connecting extremism to British colonial history and contemporary imperialist order.

The film's most important contribution could be attributed to its theoretical implication, a significance that reinforces the worth of postcolonial literature. The film shows how a historical form of colonial violence sets a template for dominating everyday life, an understanding that challenges all those functional academic approaches in which imperialism is denied having any role in regulating postcolonial lives. This approach celebrates individual freedom while ignoring hierarchical patterns of State power and neo-imperialism. Silent Waters defies this voluntarism: Ayesha is a character situated at the intersection of a traumatic past and a turbulent present. By throwing herself into the village's well, this character signifies the truth of a 
postcolonial subject - a life caught in the web of imperialist oppression, a violent revival of the spectre of a traumatic past.

Finally, looking from the perspective of organized State violence and imperialist oppression, Silent Waters is a representation of a toxic hegemonic process, which shows how a steady flow of silent water has started to inundate Pakistani society, creating ideological justification for religious extremism the world over. In view of the increasing incidents of terrorism the world over, the film is more relevant today than it was before.

\section{Funding acknowledgement:}

The author(s) received no financial support for the research, authorship, and/or publication of this article.

Declaration of conflicting interests:

None

\section{References}

Ali, T. (2003). The clash of fundamentalisms: Crusades, jihads and modernity. Verso.

BBC News. (2003, August 18). Swiss honour Pakistani movie. http://news.bbc.co.uk/2/hi/entertainment/3159257.stm

Blumer, H. (1986). Symbolic interaction: Perspective and method. University of California.

Blumer, H. (2004). George Herbert Mead and human conduct. Alta Mira.

Butalia, U. (2000). The other side of silence: Voices from the partition of India. Duke University.

Butt, K. M., \& Shahid, J. (2012). Position of Pakistani women in $21^{\text {st }}$ century: A long way to go. The Journal of Political Science, 30, 69-98. http://ps.gcu.edu.pk/wpcontent/uploads/2015/02/Dr.-Khalid-Manzoor-Butt.pdf

Collins, P. (2008). Black feminist thought: Knowledge, consciousness, and the politics of empowerment. Routledge.

Dawn (2011, Oct. 14). A history of religious violence. https://www.dawn.com/news/663772/ahistory-of-religious-violence

Deveaux, M. (1994). Feminism and empowerment: A critical reading of Foucault. Feminist Studies, 20(2), 223-247. https://doi.org/10.2307/3178151

Economic Times. (2020, Feb. 27). Religious minorities continue to face violence in Pakistan: UN rights chief. Economic Times. https://m.economictimes.com/news/international/world-news/religious-minoritiescontinue-to-face-violence-in-pakistan-un-rightschief/amp_articleshow/74338157.cms

Ellis-Petersen, H. (2020, July 08). Islamic activists halt construction of first Hindu temple in Islamabad. The Guardian. https://amp.theguardian.com/world/2020/jul/08/pakistanshri-krishna-hindu-temple-construction-halted-islamabad

Ellis-Peterson, H. (2020, March 01). Inside Delhi: Beaten, lynched and burnt alive. The Guardian. https://amp.theguardian.com/world/2020/mar/01/india-delhi-after-hindumob-riot-religious-hatred-nationalists 
Foucault, M. (1978). Discipline and punish: The birth of the prison. Vintage.

Gettleman, J., Raj, S., \& Yasir, S. (2020, Feb. 25). New Delhi streets turn into battleground: Hindus vs. Muslims. The Newyork Times. https://www.nytimes.com/2020/02/25/world/asia/new-delhi-hindu-muslimviolence.html

Haqqani, H. (2005). Pakistan: Between mosque and military. Carnegie Endowment for International Peace.

Hays, S. (1994). Structure and agency and the sticky problem of culture. Sociological Theory, 12(1), 57-72. https://doi.org/10.2307/202035

Jalal, A. (2014). The struggle for Pakistan: A muslim homeland and global politics. Harvard University.

Kara Awards. (2003). Karachi international film festival. https://www.karafilmfest.com/pastkaras_2003/pastkaras_2003_awardcitations.shtml

Macrotrends. (2018). Pakistan rural population 1960-2020. https://www.macrotrends.net/countries/PAK/pakistan/ruralpopulation\#: :text=Pakistan\%20Rural\%20Population\%20\%20Historical\%20Data\%20\%20,\%20\%201.76\%25\%20\%2055\%20more\%20rows\% $\underline{20}$

Mansoor, H. (2019, July 17). Sindh Assembly raises alarm over kidnapping, forced conversion of Hindu girls in Sindh. DAWN. https://www.dawn.com/news/1494475

Mark, A., \& Yousaf, M. (2001). The bear trap: The defeat of a superpower. Casemate.

Mead, G. H. (1962). Mind, self and society: From the standpoint of a social behaviorist. University of Chicago.

Pakistan Bureau of Statistics. (2017). $6^{\text {th }}$ population \& housing census-2017. http://www.pbs.gov.pk/content/block-wise-provisional-summary-results-6thpopulation-housing-census-2017-january-03-2018

Pascale, C. M. (2011). Cartographies of knowledge: Exploring qualitative epistemologies. Sage.

Rashid, A. (2009). Descent into chaos: The US and the disaster in Pakistan, Afghanistan and Central Asia. Penguin.

Saigol, R. (2016). Feminism and the women's movement in Pakistan actors, debates and strategie. Friedrich-Ebert-Stiftung.

The Nation. (2018, May 30). Religious intolerance towards minorities increasing in Pakistan: UNCIRF. $\quad$ https://nation.com.pk/30-May-2018/religious-intolerance-towardsminorities-increasing-in-pakistan-uncirf

Zia, A. S. (2018). Faith and feminism in Pakistan: Religious agency or secular autonomy? Sussex Academic. 